\title{
AT II Receptor Blockade and Renal Denervation: Different Interventions with Comparable Renal Effects?
}

\author{
Kristina Rodionova ${ }^{a}$ b Martin Hindermann ${ }^{a}$ Karl Hilgers $^{a}$ Christian Ott $^{a}$ b \\ Roland E. Schmieder ${ }^{a}$ Mario Schiffer ${ }^{a}$ Kerstin Amann ${ }^{c}$ Roland Veelken ${ }^{a}$ b \\ Tilmann Ditting ${ }^{a, b}$ \\ aDepartment of Department of Internal Medicine 4 (Nephrology und Hypertension), University of Erlangen, \\ Erlangen, Germany; ${ }^{b}$ Department of Department of Internal Medicine 4 (Nephrology und Hypertension), Paracelsus \\ Private Medical School, Klinikum Nuremberg, Nuremberg, Germany; 'Department of Nephropathology, University \\ of Erlangen, Erlangen, Germany
}

\section{Keywords}

Renal sympathetic innervation · Angiotensin II · Congestive heart failure $\cdot$ Renal nerve ablation $\cdot$ Renal function

\begin{abstract}
Background: Angiotensin II (Ang II) and the renal sympathetic nervous system exert a strong influence on renal sodium and water excretion. We tested the hypothesis that already low doses of an Ang II inhibitor (candesartan) will result in similar effects on tubular sodium and water reabsorption in congestive heart failure (CHF) as seen after renal denervation (DNX). Methods: Measurement of arterial blood pressure, heart rate (HR), renal sympathetic nerve activity (RSNA), glomerular filtration rate (GFR), renal plasma flow (RPF), urine volume, and urinary sodium. To assess neural control of volume homeostasis, 21 days after the induction of CHF via myocardial infarction rats underwent volume expansion ( $0.9 \% \mathrm{NaCL} ; 10 \%$ body weight) to decrease RSNA. $\mathrm{CHF}$ rat and controls with or without DNX or pretreated with the Ang II type-1 receptor antagonist candesartan (0.5 ug i.v.) were studied. Results: CHF rats excreted only $68+10.2 \%$ of the volume load ( $10 \%$ body weight) in $90 \mathrm{~min}$. CHF rats
\end{abstract}

karger@karger.com www.karger.com/kbr

Karger!
(C) 2021 The Author(s)

Published by S. Karger AG, Basel

This is an Open Access article licensed under the Creative Commons Attribution-NonCommercial-4.0 International License (CC BY-NC) (http://www.karger.com/Services/OpenAccessLicense), applicable to the online version of the article only. Usage and distribution for commercial purposes requires written permission. pretreated with candesartan or after DNX excreted from 92 to $103 \%$ like controls. Decreases of RSNA induced by volume expansion were impaired in CHF rats but unaffected by candesartan pointing to an intrarenal drug effect. GFR and RPF were not significantly different in controls or CHF. Conclusion: The prominent function of increased RSNA - retaining salt and water - could no longer be observed after renal Ang II receptor blockade in CHF rats.

(C) 2021 The Author(s) Published by S. Karger AG, Basel

\section{Introduction}

It has been known since the 19th century that renal sympathetic innervation influences the salt and water excretion of the kidney: increased sympathetic nerve activity leads to sodium and fluid retention [1]. For years a large number of experimental studies have shown that in hypertension, the renal sympathetic nerve activity (RSNA) is increased [2, 3].

Somewhat less attention was paid to the fact that even in normotensive volume retaining disorders, the clinically most important of which is congestive heart failure 
Fig. 1. Flowchart of experimental procedures. $\mathrm{CHF}$ (induction of CHF by left coronary artery ligature); $\mathrm{BP}$, blood pressure; $\mathrm{HR}$, heart rate; RSNA, renal sympathetic nerve activity; GFR, glomerular filtration rate; RPF, renal plasma flow; UV, urinary volume excretion; $\mathrm{U}_{\mathrm{NA}} \mathrm{V}$, urinary sodium excretion; $\mathrm{CHF}$, congestive heart failure (for further details see text).

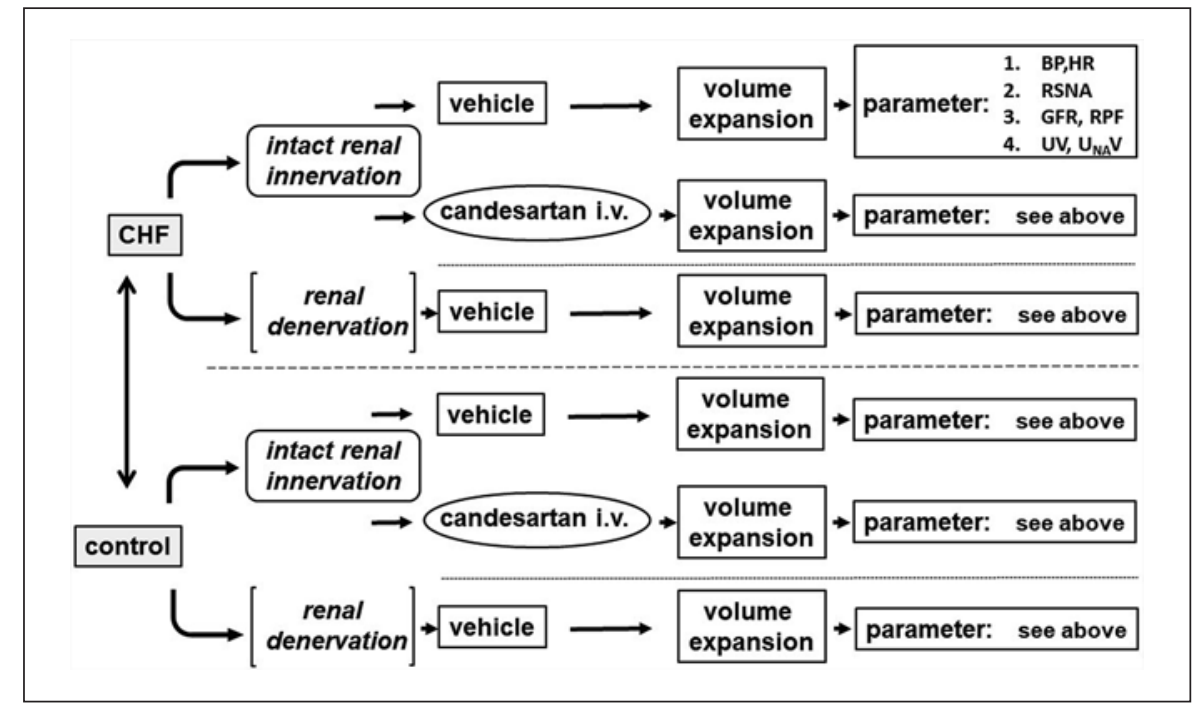

(CHF), there is an increase in sympathetic nerve activity to the kidney $[4,5]$. Although the effects of renal nerve ablation in arterial hypertension have been studies for considerable time [6-8], it is only in the last 10 years that the effects of renal denervation (DNX) in patients with heart failure have been studied [9-12].

Renal nerve ablation has been tried in patients suffering from CHF with positive [13-16] and negative results $[17,18]$. Reviews and meta-analyses on renal nerve ablation in heart failure suggest a potential benefit of the intervention for patients with heart disease, but there is a lack of larger prospective studies [9-12].

On the other hand, intrarenal effects of sympathetic innervation (namely on glomeruli, tubuli, and juxtaglomerular apparatus) can also be considerably influenced by medication, in particular by the administration of $\alpha$ sympatholytics, $\beta 1$ sympatholytics, and inhibitors of the renin-angiotensin system [3]. Especially with regard to intrarenal effects of angiotensin II (Ang II), we were able to show in earlier studies that low doses of an inhibitor of Ang II receptors led to enhanced normalized sodium and water excretion no longer influenced by acute and chronic increases of RSNA [19, 20].

In these experiments, salt and water excretion as well as glomerular filtration rate (GFR) and renal plasma flow (RPF) were measured to accurately evaluate the effect of sympathetic nerve fibers on the kidney via functional parameters. Hence, we tested the hypothesis that low doses of an Ang II inhibitor (candesartan) will result in similar effects on tubular sodium and water reabsorption in $\mathrm{CHF}$ as seen after DNX.

\section{Material and Methods}

Preparation of Animals and Experimental Procedures

Male Sprague-Dawley rats, 250-300 g body weight (Charles River Wiga, Sulzfeld, Germany) were kept in a room at $24 \pm 2^{\circ} \mathrm{C}$ with $60-80 \%$ humidity and fed a normal diet containing $0.2 \%$ sodium with free access to tap water. Procedures were in accordance with the National Institutes of Health Guide for the Care and Use of Laboratory Animals and approved by the respective government agencies (Mittelfranken, Ansbach and Unterfranken, Würzburg, Germany).

\section{Experimental CHF}

As previously described [21] ligation of the intraventricular coronary artery was used to produce chronic CHF. Rats were anesthetized with methohexital sodium (50 mg/kg i.p.): after mechanical ventilation with room air had been started, the heart was accessed via a midline thoracotomy, the intraventricular coronary artery was ligated and the thorax closed. All subsequent studies were started no earlier than 3 weeks after coronary artery ligation. SHAM-treated rats were always prepared in parallel.

\section{Renal Denervation}

Two weeks after coronary artery ligature, groups of rats with either CHF or controls were bilaterally denervated or underwent sham-operations. Following bilateral flank incisions, DNX was started by surgically stripping the renal arteries and veins of the adventitia, cutting all renal nerve bundles under a dissection microscope $(25 \times)$, and treating the vessels with a solution of $10 \%$ phenol in 95\% ethanol [19].

\section{Experimental Setup}

Three weeks after coronary artery ligature, in anesthetized rat polyethylene catheters were inserted in the arterial or venous femoral vessels and a further polyethylene tubing into the bladder for urine collection [19]. Recordings of right-sided RSNA were accomplished as previously described in rats without DNX [22-24]. Through a lateral approach, renal nerve fibers were dissected free from connective tissue and placed on a bipolar electrode. The nerve signals were full- 
Table 1. Body weights in grams (g) of rats with $\mathrm{CHF}$ and Controls

\begin{tabular}{lll}
\hline & Intact renal innervation, $n=20$ & $\mathrm{DNX}, n=10$ \\
\hline Control, g & $306 \pm 10$ & $300 \pm 7$ \\
CHF, g & $280 \pm 9$ & $291 \pm 12$ \\
\hline
\end{tabular}
tion.

CHF, coronary artery ligature; mean SE; DNX, renal denerva-

wave rectified and integrated over 1-s intervals with a commercially available data acquisition and analysis software (SciWorks 7.2, DataWave Technologies, Loveland, CO, Loveland, CO, USA).

\section{Assessment of Doses of the ANG II AT $T_{1}$-Receptor Antagonist Candesartan}

In a separate group of normal Sprague-Dawley rats, 3 doses of the Ang II receptor antagonist candesartan $(0.5,1.5$, and $3 \mu \mathrm{g}$ iv) were injected to inhibit the effects of Ang II [25]. To test for the blockade of systemic Ang II AT 1 receptors, we administered $20 \mathrm{ng}$ of ANG II intravenously $10 \mathrm{~min}$ before and $10 \mathrm{~min}$ after the injection of candesartan. The lowest dose of candesartan blocked the hemodynamic responses and was used in the subsequent studies.

Renal responses to 10 min periods of a nonpressor infusion of Ang II (13 ng/min) on urine volume (UV) and urinary sodium excretion $\left(\mathrm{U}_{\mathrm{Na}} \mathrm{V}\right)$ were studied. Physiological saline was infused intravenously at a rate of $60 \mu \mathrm{L} / \mathrm{min}$ until a steady state was achieved (saline input $=$ urinary output). Then, after 3 control periods, a nonpressor dose of Ang II was added to the infusion for $10 \mathrm{~min}$, followed by another $210 \mathrm{~min}$ recovery periods without Ang II. One group of rats was pretreated with saline, another received $0.5 \mu \mathrm{g}$ i.v. of the $\mathrm{AT}_{1}$-receptor antagonist candesartan (bolus injection of 30 $\mu \mathrm{L}$ volume). $\mathrm{UV}$ and $\mathrm{U}_{\mathrm{NA}} \mathrm{V}$ in these groups were evaluated.

\section{Volume Expansion after Low-Dose ANG II Receptor Blockade} (0.5 $\mu \mathrm{g}$ Candesartan)

As soon as the surgical preparations were finished, urine was collected over $15 \mathrm{~min}$ or $30 \mathrm{~min}$ periods. Physiological saline was administered at a rate of $60 \mu \mathrm{L} / \mathrm{min}$ for the entire duration of the experiments. Inulin and PAH clearances were determined as previously described [19].

After having achieved "steady state," the Ang II AT 1 -receptor antagonist candesartan $(0.5 \mu \mathrm{g}$ iv) or vehicle $(0.9 \% \mathrm{NaCl})$ were injected as a bolus ( $30 \mu \mathrm{L}$ volume iv). After 215 min control periods all rats received a volume challenge with saline for $30 \mathrm{~min}(10 \%$ body weight). Thereafter, there were 3 further periods of $30 \mathrm{~min}$ for recovery. Blood samples of $150 \mu \mathrm{L}$ were collected at the midpoint of each period for evaluation of GFR and RPF. At the end of the experiments, a catheter was inserted via the right carotid artery into the left ventricle and was used to measure left ventricular enddiastolic pressure [21] providing a more direct assessment of myocardial contractility as compared to echocardiographic methods [26]. Finally, $3 \mathrm{mg}$ of the ganglionic blocking agent trimetaphamcamsylate (Hoffmann-La Roche, Basel, Switzerland) was administered to inhibit postsynaptic RSNA. The background activity that was still present was subtracted from the activity recorded throughout the experiments. A flowchart of the main experiments of the project is presented in Figure 1.

Sympathetic Innervation and Renal at II Receptors

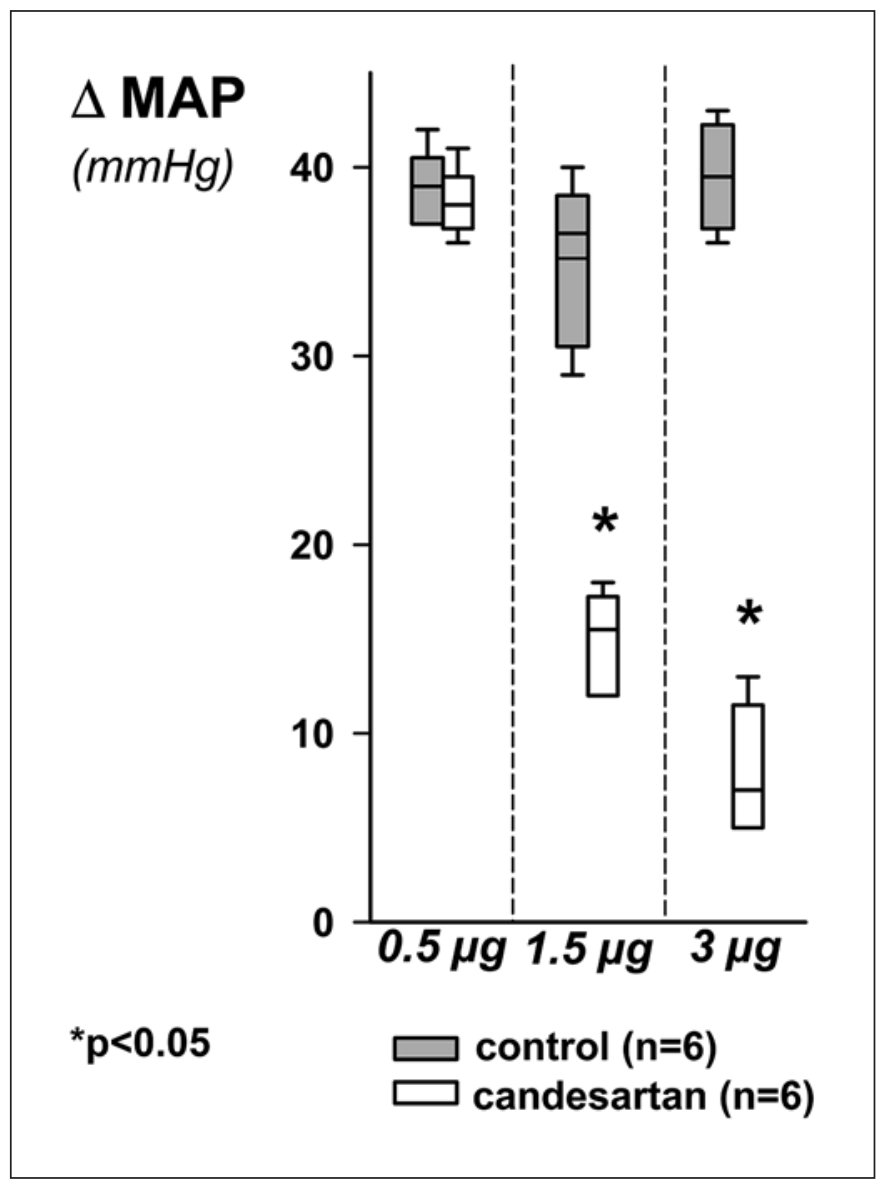

Fig. 2. Effects of 3 doses $(0.5,1.5$, and $3 \mu \mathrm{g})$ of the Ang II $\mathrm{AT}_{1}$ receptor blocker, candesartan, on the mean arterial BP response to $20 \mathrm{ng}$ of Ang II. All data are presented as box and whisker plots $(n=6) .{ }^{*} p<0.05$. Asterisks represent significant differences from the blood pressure increases to Ang II injections in controls. $0.5 \mu \mathrm{g}$ did not significantly affect the response to Ang II, whereas 1.5 and $3 \mu \mathrm{g}$ candesartan blunted the response to the peptide. Ang II, angiotensin II; BP, blood pressure.

\section{Urine Analysis}

Urine volume was measured gravimetrically. Urine and plasma sodium concentrations were assessed by flame photometry. Values for urinary volume were expressed per gram body weight. Urine and plasma inulin and PAH concentrations were determined by the anthrone and ethylenediamine methods to assess inulin and PAH clearances [19].

\section{Statistics}

Integrated RSNA was recorded as $\mu \mathrm{V} \times \mathrm{s}$. Baseline values of RSNA $(\mu \mathrm{V} \times \mathrm{s})$, measurement of arterial blood pressure $(\mathrm{mm}$ $\mathrm{Hg})$, and heart rate (bpm) were analyzed using one-way ANOVA with Dunnett's post hoc test. Statistical significance was defined as $p<0.05$. Data are given as group means \pm SE in the results section or tables and displayed in the figures as box and whiskers plots. SigmaStat 3.5 (Systat Software) was used for statistical analysis. 
Fig. 3. Effects of a nonpressor infusion of ANG II (13 ng/min) on UV and sodium excretion rate $\left(\mathrm{U}_{\mathrm{Na}} \mathrm{V}\right)$ in rats. One group (ANG II) was pretreated with saline whereas 1 further group received an intravenous bolus injection of $0.5 \mu \mathrm{g}$ of the Ang II $\mathrm{AT}_{1}$ receptor candesartan (ANG II + candesar$\tan )$. All data are presented as box and whiskers $(n=6){ }^{*} p<0.05$. Asterisks represent significant differences between groups. $\mathrm{UV}$ and $\mathrm{U}_{\mathrm{Na}} \mathrm{V}$ dropped significantly during ANG II infusion in control rats but not in candesartan treated animals. UV, urine volume; $\mathrm{U}_{\mathrm{Na}} \mathrm{V}$, urinary sodium excretion.

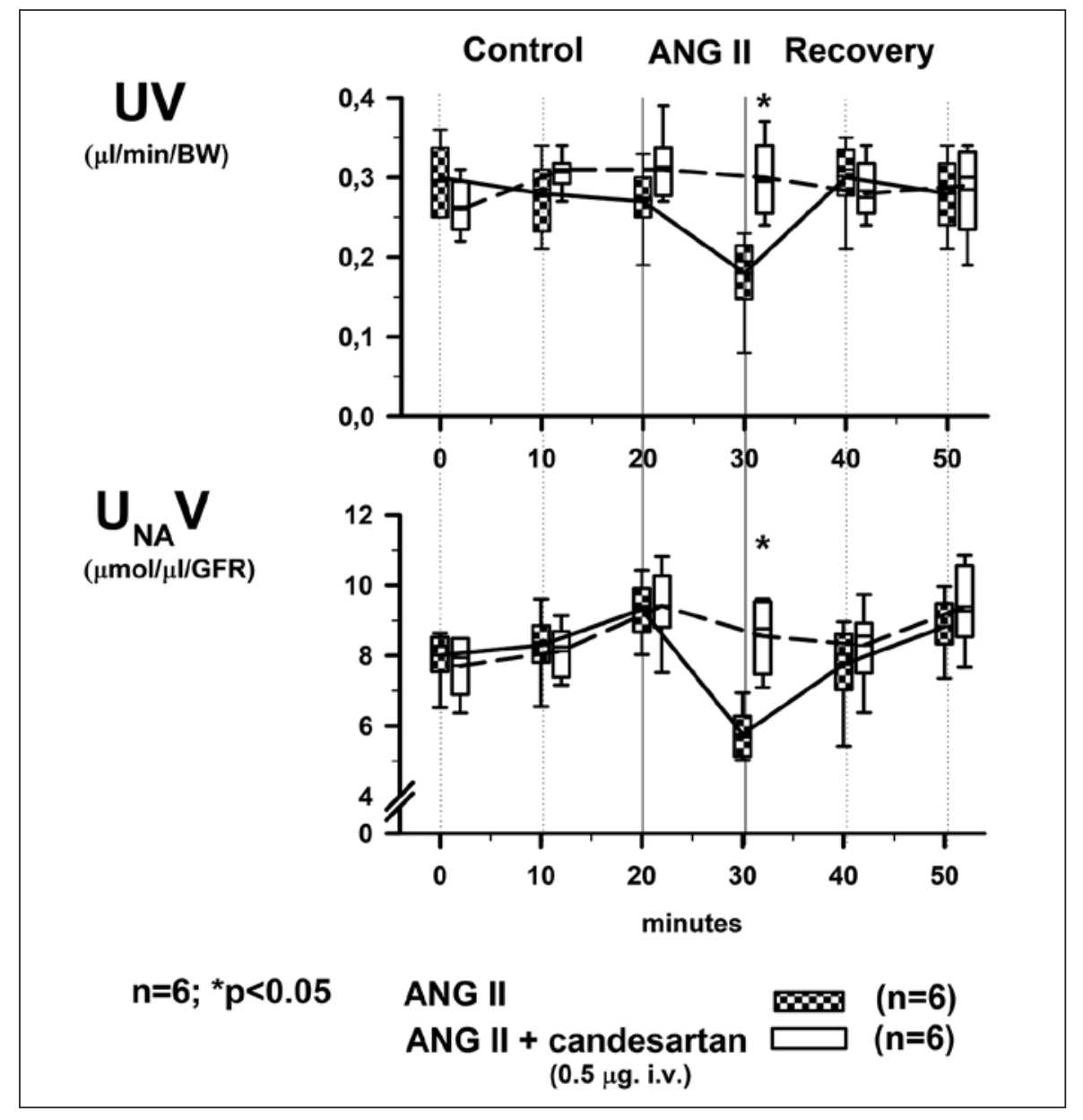

\section{Results}

Mean body weight of heart failure animals and controls are given in detail in Table 1. Of note, the body weight of heart failure rats and controls were not significantly different. Hence, significant volume retention in these rats suggesting a severe edematous state had not yet occurred at his point in time.

The heart weight/body weight ratio was significantly higher in CHF rats as than controls $(0.49 \pm 0.07 \%$ in $\mathrm{CHF}$ vs. $0.35 \pm 0.08$ in controls). Left ventricular end-diastolic pressure was significantly increased in heart failure rats $(18.9 \pm 8.1 \mathrm{~mm} \mathrm{Hg})$ as compared to control animals (2.9 $\pm 1.2 \mathrm{~mm} \mathrm{Hg}$ ). Both parameters suggest overt CHF in our experimental animals.

\section{Assessment of Doses of the ANG II AT $T_{1}$-Receptor \\ Antagonist Candesartan}

To test for the blockade of systemic Ang II $\mathrm{AT}_{1}$-receptors with the Ang II receptor antagonist candesartan,
$20 \mathrm{ng}$ of Ang II was injected intravenously $10 \mathrm{~min}$ before and $10 \mathrm{~min}$ after the administration of candesartan. The results are shown in Figure 2. The higher doses blocked the pressor response to exogenous Ang II significantly by $69 \pm 7 \%(1.5 \mu \mathrm{g})$ and $82 \pm 5 \%(3 \mu \mathrm{g})$, respectively. The lowest dose $(0.5 \mu \mathrm{g})$ did not significantly affect the pressor response to exogenous Ang II. However, the lowest dose of the AT1-receptor inhibitor proved to be still effective on renal AT1 receptors, since the water and sodium retention that was induced by a nonpressor dose of Ang II $(13 \mathrm{ng} / \mathrm{min})$, could be impaired after pretreatment with $0.5 \mu$ g candesartan (Fig. 3).

\section{Volume Expansion after Low-Dose ANG II Receptor}

Blockade (0.5 $\mu$ g Candesartan)

As displayed in Figure 4, rats with intraventricular coronary artery ligature excreted only $6,810.2 \%$ of the administered volume load. In heart failure rats pretreated with the Ang II AT1 inhibitor candesartan or after DNX as well as in all control groups the respective value ranged 
Fig. 4. Cumulative excretion of a $30 \mathrm{~min}$ volume expansion (VE) with saline (10\% body weight) during volume expansion and $1.5 \mathrm{~h}$ thereafter in conscious rats with CHF (upper panel A) or control animals without coronary artery ligature (lower panel B). Animals were either untreated, DNX or pretreated with $0.5 \mu \mathrm{g}$ of the Ang II $\mathrm{AT}_{1}$ receptor antagonist candesartan intravenously (ANG II Inhib.). All data are presented as box and whiskers $(n=6) .{ }^{*} p<$ 0.05 . Asterisks represent significant differences between groups. DNX or pretreatment with the ANG II inhibitor restored the cumulative excretion of the volume load to $100 \%$ in the observation period whereas untreated rats with coronary artery ligature excreted significantly less. DNX, renal denervation; $\mathrm{CHF}$, coronary artery ligature.
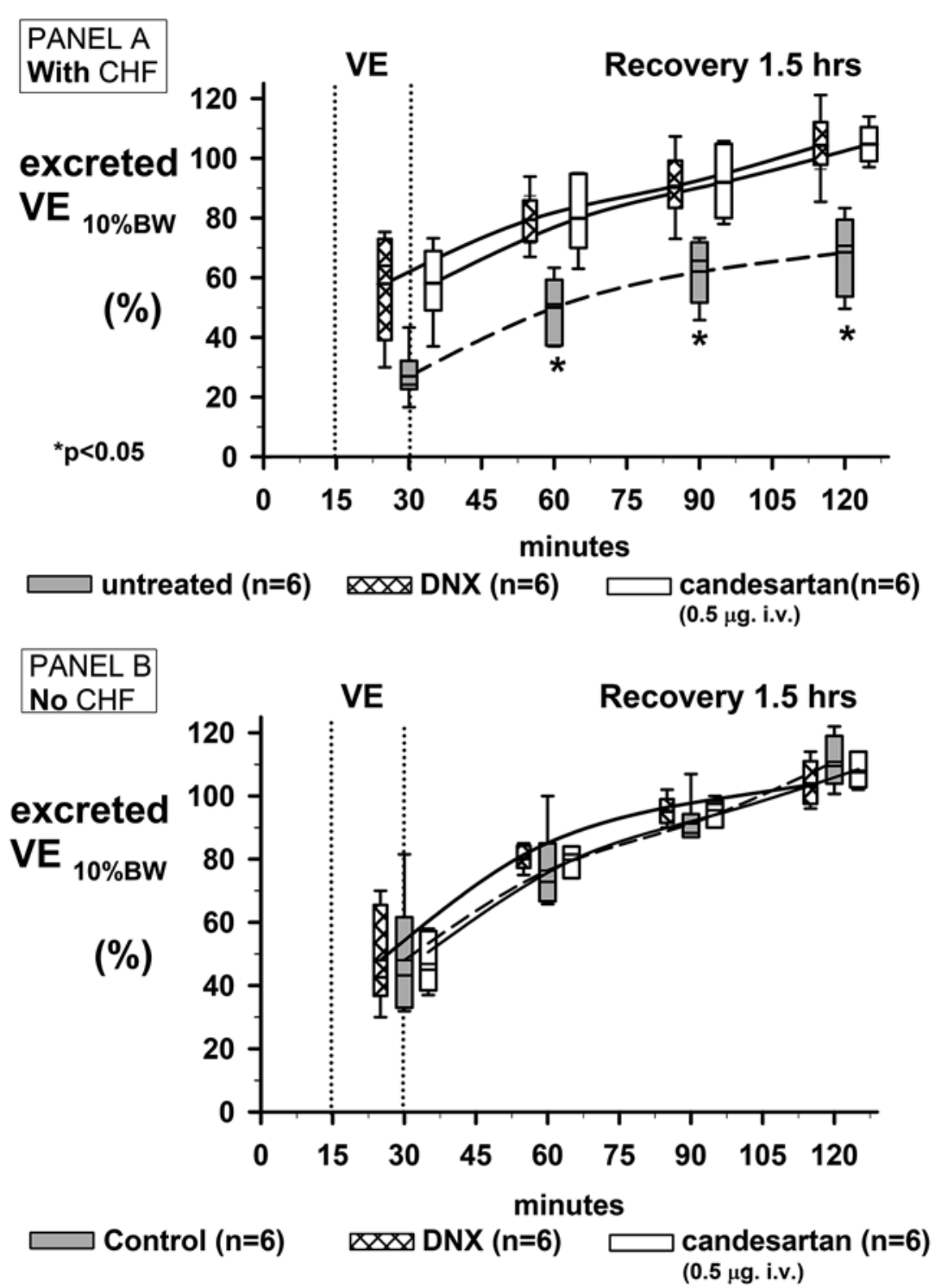

from 92 to $103 \%$ which was significantly greater than the excretion rate of the untreated heart failure animals. As displayed in Table 2 urinary flow rate (UV) and urinary $\mathrm{Na}$ excretion $\left(\mathrm{U}_{\mathrm{NA}} \mathrm{V}\right)$ increased and reached maximum levels during the volume expansion period and returned to control values during the third 30 periods of recovery. This pattern was similar for all 6 groups of animals with no significant differences among them. Animals with coronary artery ligature, however, exhibited a significantly smaller increase in $\mathrm{UV}$ and $\mathrm{U}_{\mathrm{NA}} \mathrm{V}$ as compared to the respective controls and the animals pretreated with the AT1 inhibitor or DNX.

Sympathetic Innervation and Renal at II Receptors
Mean changes of RSNA in rats with coronary artery ligature and control animals during volume expansion and recovery are displayed in Figure 5, respectively. Basal absolute RSNA levels were $500 \pm 39 \mu \mathrm{V}$ for the heart failure groups and for controls $370 \pm 34 \mu \mathrm{V}$. In rats with coronary artery ligature, the maximum decrease in RSNA occurred after $20 \mathrm{~min}$ and in control animals $15 \mathrm{~min}$ after the onset of volume expansion. There was no significant difference in the maximum depression of RSNA. In the first 30 min after cessation of volume expansion, RSNA returned to control values in rats with coronary artery ligature and remained there for the duration of the recov- 
Table 2. Renal perfusion parameters of rats with congestive heart failure and controls

\begin{tabular}{|c|c|c|c|c|c|}
\hline Urinary flow rate, $\mu \mathrm{L} / \mathrm{min} / \mathrm{BW}$ & C, 15 min & $\mathrm{VE}, 30 \mathrm{~min}$ & $\operatorname{Rec} 1,30 \mathrm{~min}$ & $\operatorname{Rec} 2,30 \mathrm{~min}$ & $\operatorname{Rec} 3,30 \mathrm{~min}$ \\
\hline \multicolumn{6}{|l|}{$\varnothing$} \\
\hline $\mathrm{CHF}$ & $0.26 \pm 0.02$ & $1.69 \pm 0.25^{*}$ & $0.93 \pm 0.11^{*}$ & $0.49 \pm 0.05^{*}$ & $0.36 \pm 0.17$ \\
\hline Control & $0.32 \pm 0.14$ & $2.49 \pm 0.11$ & $1.06 \pm 0.09$ & $0.58 \pm 0.13$ & $0.38 \pm 0.04$ \\
\hline \multicolumn{6}{|l|}{ Candesartan } \\
\hline $\mathrm{CHF}$ & $0.31 \pm 0.05$ & $2.42 \pm 0.16$ & $1.18 \pm 0.10$ & $0.56 \pm 0.12$ & $0.37 \pm 0.07$ \\
\hline Control & $0.30 \pm 0.02$ & $2.53 \pm 0.15$ & $1.23 \pm 0.13$ & $0.50 \pm 0.06$ & $0.35 \pm 0.04$ \\
\hline \multicolumn{6}{|l|}{ DNX } \\
\hline $\mathrm{CHF}$ & $0.33 \pm 0.3$ & $2.52 \pm 0.15$ & $1.22 \pm 0.16$ & $0.57 \pm 0.08$ & $0.41 \pm 0.07$ \\
\hline Control & $0.32 \pm 0.05$ & $2.54 \pm 0.17$ & $1.17 \pm 0.14$ & $0.50 \pm 0.11$ & $0.36 \pm 0.05$ \\
\hline Urinary $\mathrm{Na}$ excretion, $\mu \mathrm{mol} / \mu \mathrm{L} / \mathrm{GFR}$ & $\mathrm{C}, 15 \mathrm{~min}$ & $\mathrm{VE}, 30 \mathrm{~min}$ & $\operatorname{Rec} 1,30 \mathrm{~min}$ & $\operatorname{Rec} 2,30 \mathrm{~min}$ & $\operatorname{Rec} 3,30 \mathrm{~min}$ \\
\hline \multicolumn{6}{|l|}{$\varnothing$} \\
\hline $\mathrm{CHF}$ & $8.55 \pm 1.09$ & $28.84 \pm 4.71^{*}$ & $24.15 \pm 5.3^{*}$ & $11.83 \pm 2.07^{*}$ & $9.44 \pm 2.01$ \\
\hline Control & $8.66 \pm 1.36$ & $59.01 \pm 2.50$ & $32.82 \pm 3.06$ & $15.43 \pm 2.16$ & $10.97 \pm 1.45$ \\
\hline \multicolumn{6}{|l|}{ Candesartan } \\
\hline $\mathrm{CHF}$ & $8.85 \pm 1.17$ & $48.43 \pm 4.62$ & $35.95 \pm 5.25$ & $15.57 \pm 2.45$ & $11.46 \pm 2.03$ \\
\hline Control & $8.39 \pm 0.89$ & $54.97 \pm 5.24$ & $33.16 \pm 3.97$ & $15.08 \pm 2.23$ & $10.14 \pm 1.66$ \\
\hline \multicolumn{6}{|l|}{ DNX } \\
\hline $\mathrm{CHF}$ & $8.43 \pm 1.24$ & $50.55 \pm 5.52$ & $35.17 \pm 5.04$ & $16.12 \pm 1.73$ & $13.41 \pm 2.27$ \\
\hline Control & $8.56 \pm 1.25$ & $54.71 \pm 3.06$ & $32.11 \pm 4.85$ & $15.13 \pm 3.34$ & $11.68 \pm 2.03$ \\
\hline
\end{tabular}

$\mathrm{CHF}$, coronary artery ligature; candesartan, pretreatment with $6 \mu$ g candesartan; DNX, renal sympathetic denervation; C, control; VE, volume expansion with saline (10\% BW); Rec, recovery; GFR, glomerular filtration rate ( $\mathrm{mL} / \mathrm{min})$; CHF, congestive heart failure. ${ }^{*} p<0.05$ from control, mean SE, $n=6$, respectively.

ery period. In control animals, however, RSNA remained depressed. RSNA was significantly different between rats with coronary artery ligature and control animals for the entire $1.5 \mathrm{~h}$ recovery period. This pattern was not influenced by the pretreatment with the Ang II AT1 inhibitor candesartan.

In none of the experimental group blood pressure, heart rate, GFR, or RPF were affected by the experimental procedures. Data for GFR and RPF are displayed in Figure $6 a, b$. Pooled data on blood pressure and heart rate are given in Table 3.

\section{Discussion}

Our data suggest that the tubular effects of increased sympathetic nerve activity (sodium and water reabsorption) can be inhibited with low doses of Ang II receptor inhibitors. This finding could be of clinical importance since effects on salt and water retention are of importance in sodium retaining disorders like $\mathrm{CHF}$.
There are several mechanisms by which RSNA and Ang II influence renal sodium and water handling leading to similar effects on sodium and water excretion in situations of increased RSNA: for example, sympathetic nerve activity stimulates the juxtaglomerular apparatus in addition to its tubular effects so that a nerve-dependent renin secretion will occur [27]. Intrarenal effects of Ang II on salt and water excretion, especially on the luminal site of the tubule [28] could influence sodium reabsorption independent of RSNA which is known to interfere with sodium reabsorption at these very sites [3].

On the other hand, our results could be seen as supporting the view in the literature that the tubular effects of increased sympathetic nerve activity (sodium and water reabsorption) are probably very dependent on intrarenal Ang II [29-31].

Regardless of the mechanisms involved, the key question is whether renal sympathetic denervation - a procedure destroying physiological control systems can provide important clinical benefits in patients with CHF (with and without hypertensive) in addition to 
Fig. 5. Effects of $30 \mathrm{~min} \mathrm{VE}$ with saline (10\% body weight) on RSNA in rats with CHF (upper panel A) or control animals without coronary artery ligature (lower panel B). Animals were either untreated, DNX or were pretreated with saline or 0.5 $\mu \mathrm{g}$ of the Ang II $\mathrm{AT}_{1}$ receptor antagonist candesartan intravenously (candesartan.). All data are presented as box and whiskers $(n=6) .{ }^{*} p<0.05$. Asterisks represent significant differences from RSNA baselines The Ang II blocker did not change the RSNA response to volume expansion in either of the groups. However, all rats with coronary artery ligature exhibited a distinctly different response pattern of RSNA to volume expansion as compared to controls. RSNA, renal sympathetic nerve activity; VE, volume expansion; DNX, renal denervation; $\mathrm{CHF}$, coronary artery ligature.

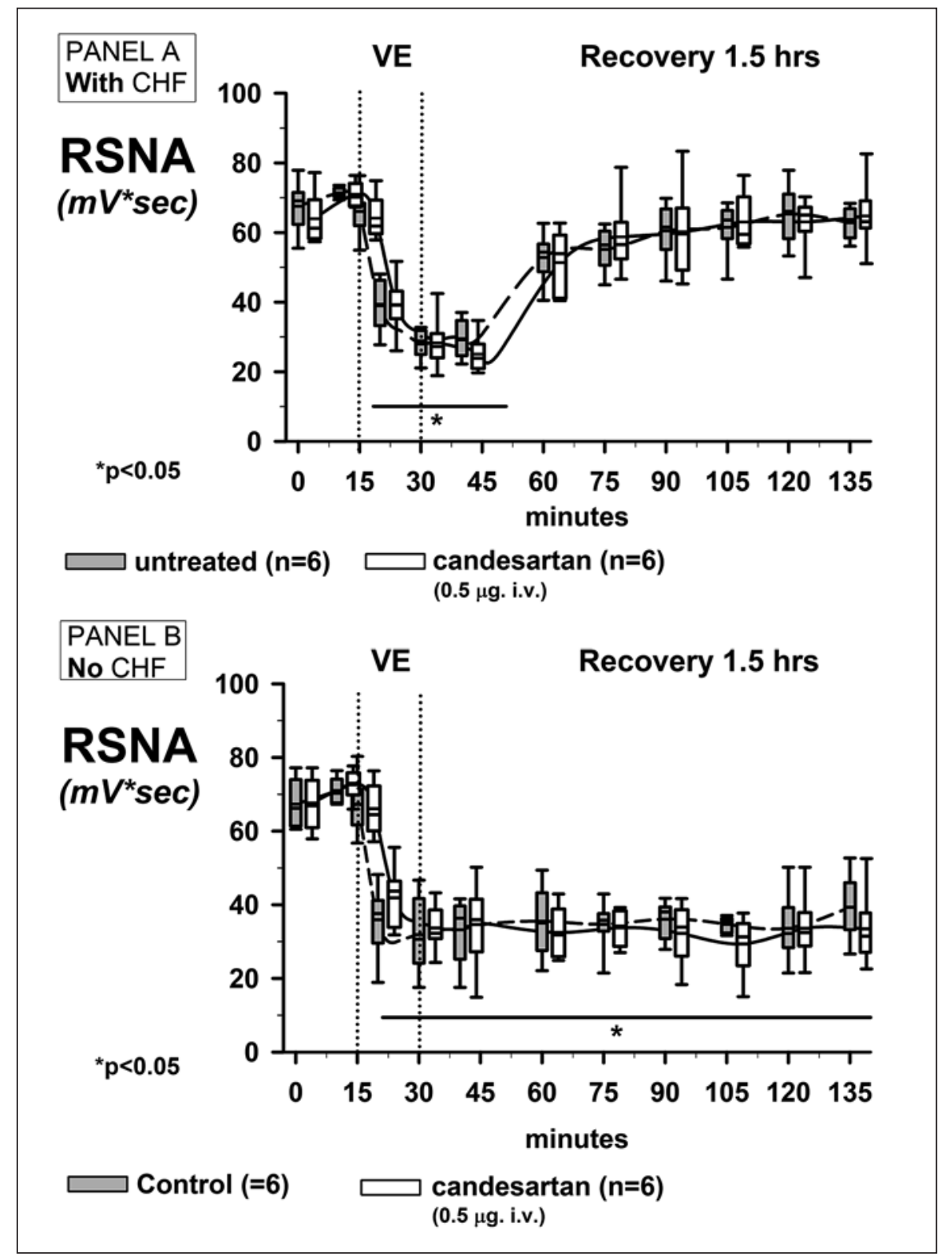

drug therapy with, for example, Ang II inhibiting therapeutics.

Renal nerve ablation physically destroys a part of the cardiovascular nervous system. But these nerves regrow and little is known of the subsequent effects on renal function [32], which complicates the issue.

Furthermore, there are hints that the sympathetic innervation of the kidney might help to maintain perfusion of the kidneys in cases of blood loss [24, 33, 34]. This could be a point to consider for elderly cardiovascular patients as more and more elderly patients are undergoing surgery [35].

Sympathetic Innervation and Renal at II Receptors
The NHE3 $\left(\mathrm{Na}^{+} / \mathrm{H}^{+}\right.$exchanger 3$)$ is the most impor$\operatorname{tant} \mathrm{Na}^{+}$transporter in the proximal tubules of the kidney [36] and is linked to Ang II and related hypertensive disorders. In vitro, nanomolar concentrations of Ang II increased NHE3 expression in cultured proximal tubule cells $[37,38]$. In vivo, low subpressor doses of Ang II also significantly increased the expression of NHE3, as well as proximal $\mathrm{Na}^{+}$reabsorption [39]. Recently, a direct relationship between Ang II and NHE3 in the proximal tubules of the kidney with impaired pressure-natriuresis response was reported [40]. 


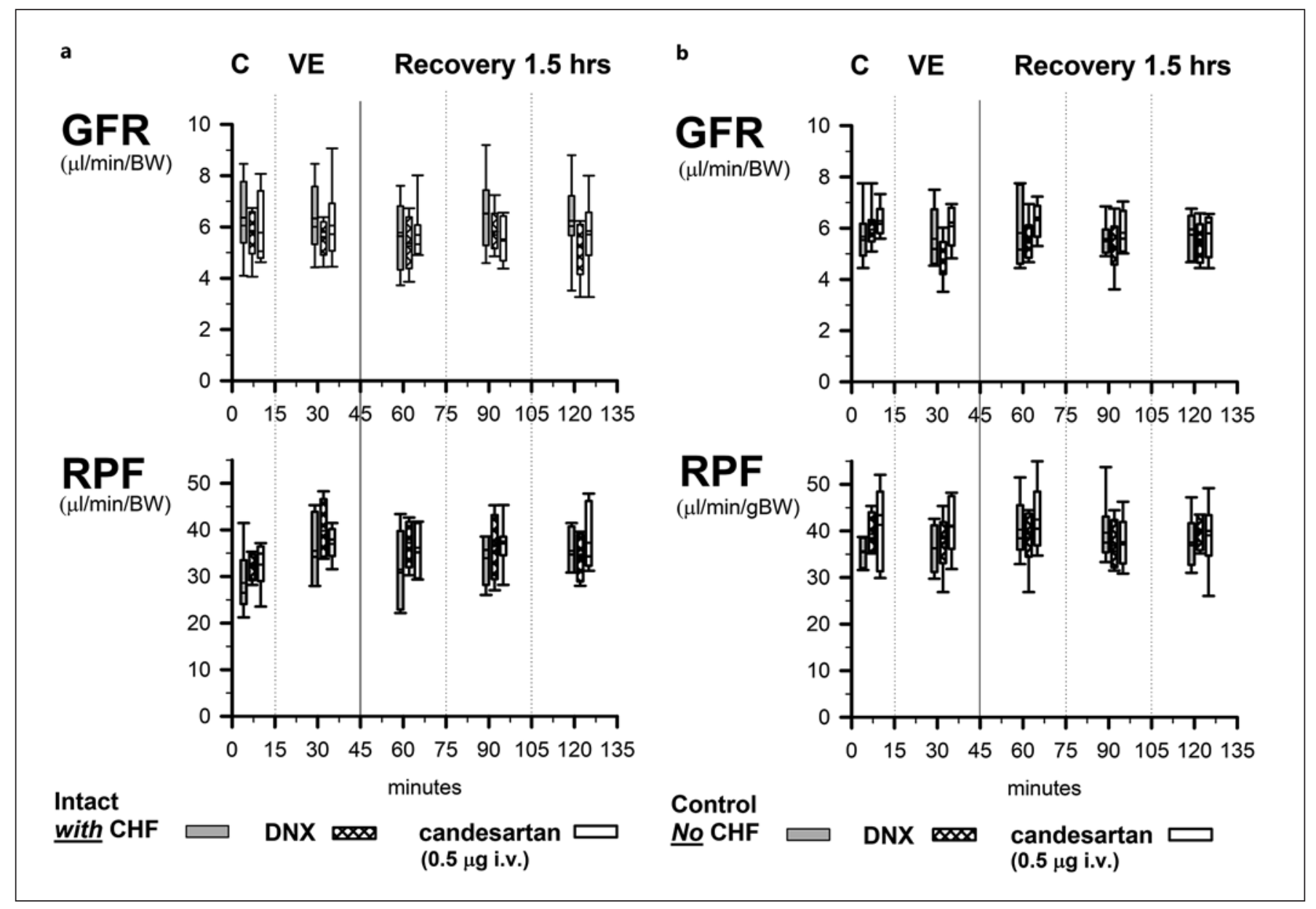

Fig. 6. a GFR and RPF of rats with CHF during control, VE and recovery in intact rats, DNX animals and animals

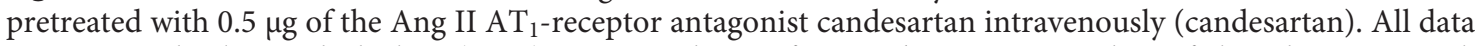
are presented as box and whiskers $(n=6)$. $\mathbf{b}$ GFR and RPF of rats without congestive heart failure during control, $\mathrm{VE}$ and recovery in intact rats, DNX and animals pretreated with $0.5 \mu \mathrm{g}$ of the Ang II $\mathrm{AT}_{1}$ receptor antagonist candesartan intravenously (candesartan). All data are presented as box and whiskers $(n=6)$. GFR, glomerular filtration rate; RPF, renal plasma flow; RSNA, renal sympathetic nerve activity; VE, volume expansion; DNX, renal denervation; $\mathrm{CHF}$, coronary artery ligature.

Furthermore, the stimulation of sodium reabsorption in the collecting ducts is said to be strongly influenced by Ang II type 1-receptor activation of epithelial Na channels and further distal transporters [41-43]. Hence, Ang II influences sodium reabsorption at least in the same tubular segments as RSNA.

Even with acute low-dose infusions of Ang II, we readily observed increased sodium and water retention in our experiments. Since only the excretion of a short saline infusion was investigated as a "classical" functional test of the renal sympathetic inhibition achieved, different experimental groups under quite similar conditions could be compared. In particular, in animals with myocardial infarc- tion, renal blood flow, and GFR were not different in the various groups of $\mathrm{CHF}$ and control rats. Furthermore, we observed that the acute administration of an Ang II inhibitor did not influence RSNA in any of the groups investigated. This observation suggests that candesartan did not influence the central generation of sympathetic nerve activity. However, candesartan might have impaired the interaction between Ang II and sympathetic nerve fibers near the tubular system. RSNA is recorded before the nerve fibers enter the kidney and travel to the tubular system. However, chronic administration of drugs inhibiting the effects of Ang II may result in a more pronounced reduction of central sympathetic outflow. This has been shown by direct 
Table 3. Pressure and HR of rats with $\mathrm{CHF}$ and controls

\begin{tabular}{lccc}
\hline Urinary Na excretion & C, 15 min & VE, 30 min & Rec 3, 30 min \\
\hline BP, mm Hg & & & \\
CHF & $114 \pm 10$ & $113 \pm 12$ & $112 \pm 12$ \\
Control & $117 \pm 12$ & $116 \pm 12$ & $114 \pm 10$ \\
\hline HR, bpm & & & \\
$\quad$ CHF & $445 \pm 28$ & $437 \pm 16$ & $440 \pm 26$ \\
Control & $440 \pm 22$ & $443 \pm 18$ & $439 \pm 13$ \\
\hline
\end{tabular}

CHF, coronary artery ligature; C, control; VE, volume expansion with saline $(10 \%$ BW); Rec, recovery; mean SE (pooled data for all CHF, or control animals, $n=30$, respectively); $\mathrm{HR}$, heart rate; $\mathrm{CHF}, \mathrm{CHF}$, congestive heart failure. nerve recordings [2]. The site of action of this chronic systemic lowering of the sympathetic nervous system may be the area postrema which contains a high concentration of Ang II receptors [44], where the blood-brain barrier is lacking allowing substances from the systemic circulation to influence central neurons [45].

Endogenous Ang II could modulate the nerve-mediated antinatriuresis and antidiuresis by either pre- or postsynaptic actions at the tubular level: presynaptic facilitation of transmitter release from sympathetic varicosities by Ang II has been demonstrated [46]. Ang II may also exhibit a postsynaptic synergism with released norepinephrine [47]: in this report, results were presented suggesting that the neurally mediated tubular responses require low levels of circulating Ang II since, when the production of peptide is inhibited, the renal nerve-induced antinatriuresis and antidiuresis is abolished but will be seen again during the infusion of Ang II. It was further argued that Ang II exerts its action at the renal nerve junctions the epithelial cells of the renal tubule. In other reports, intrarenal Ang II facilitated alpha-adrenoceptor-mediated sodium reabsorption in response to stress via post- and presynaptic Ang II receptors [48]. Hence, Ang II may have putative importance for the tubular effects of sympathetic renal nerve activity on salt and water excretion with acute increases in RSNA [19] as well as with chronic activity increases in liver cirrhosis [20] and CHF.

In animal models, DNX-induced some improvement in the heart failure groups that exhibited markedly increased sympathetic nerve activity [49]. Reports on renal nerve ablation in patients suffering from CHF have not always shown consistent benefits $[17,18]$. In a prospective single-arm feasibility study using renal nerve ablation in patients with systolic heart failure and renal dysfunction, significant reductions in NT-proBNP but no further

Sympathetic Innervation and Renal at II Receptors improvements of cardiac or renal function could be demonstrated [14]. On the other hand, a study using 60 patients suffering from $\mathrm{CHF}$ with reduced ejection fraction reported an improvement of cardiac function as assessed by the NYHA classification after renal nerve ablation accompanied by increased 6 min walk distance and favorable changes in NT proBNP [13]. Furthermore in a single-center, prospective, randomized, and controlled study, renal nerve ablation in 60 patients with chronic systolic heart failure improved cardiac function as well as exercise tolerance [16]. Finally, in a small feasibility, study renal nerve ablation was found to benefit patients in early-stage heart failure [15].

In none of these investigations did the study design rigorously control the concomitant medications the patients were using. Hence, the effects of Ang II inhibition on the tubular sodium and water reabsorption or the inhibitory effects of beta-adrenoceptor inhibitors on the juxtaglomerular apparatus that releases renin upon increased sympathetic nerve activity [50] cannot be appropriately discussed in the context of CHF.

Afferent nerve fibers are found in and travelling from the kidneys to the central nervous system [51]. Resting afferent renal nerve activity was reported to be increased in rats with CHF. This finding was interpreted as suggesting that in CHF altered renal afferent nerve traffic might be responsible for the observed enhanced central sympathetic outflow [51]. The mechanism may involve altered nitric oxide production in the hypothalamic paraventricular nucleus since specific renal afferent denervation has been shown to prevent the decrease of neuronal nitric oxide in the paraventricular nucleus in heart failure rats which contributes to the downregulation of sympathetic activity [51].

In animal models of hypertension, a purely afferent denervation of the kidneys via dorsal rhizotomy has been 
found to reduce blood pressure [52]. These results suggest an important role of afferent renal nerve activity is likely to influence central sympathetic outflow. Since besides the efferent sympathetic innervation of the kidney there is obviously also an afferent nerve supply from the kidney, which so far poorly understood influences the generation of sympathetic activity, there is obviously not only one reason to make indications for renal nerve ablation in whatever disease very carefully.

\section{Acknowledgements}

We thank Dr. Emilio Badoer (School of Health and Biomedical Sciences, RMIT University, Melbourne, Australia) for expert assistance in editing style and language of the manuscript.

\section{Statement of Ethics}

All of the procedures performed on animals were done in accordance with the National Institutes of Health Guide for the Care and Use of Laboratory Animals and approved by the local government agency (Regierung von Mittelfranken, Ansbach, Germany).

\section{Conflict of Interest Statement}

The authors have no conflicts of interest to declare.

\section{Funding Sources}

K. Amann and R. Veelken were supported by a grant-in-aid from the Deutsche Forschungsgemeinschaft (AM 93/10-1; VE 104/4-1) and the Interdisciplinary Center for Clinical Research (IZKF) of the University Erlangen.

\section{Author Contributions}

K. Rodionova conceived and designed the study, performed research, analyzed data, and wrote the paper; $M$ Hindermann performed research, analyzed data, and contributed new methods to better record sympathetic nerve activity; KF Hilgers analyzed data and helped improving data acquisition; C Ott and R Schmieder analyzed data; $\mathrm{M}$ Schiffer helped with improved procedures to evaluate renal perfusion; K. Amann designed the study and analyzed data; R Veelken and T Ditting conceived the study, performed research, analyzed data, and wrote the paper.

\section{References}

1 Bernard C. Leçons sur les Propriétés et les Altérations Pathologiques des Liquides de L’Organisme. Paris: Bailliére et Fils; 1859. vol. 2, 170 .

2 DiBona GF. Sympathetic nervous system and the kidney in hypertension. Curr Opin Nephrol Hypertens. 2002;11(2):197-200.

3 DiBona GF, Esler M. Translational medicine: the antihypertensive effect of renal denervation. Am J Physiol. 2010 Feb;298(2):R245-53.

4 DiBona GF, Sawin LL. Role of renal nerves in sodium retention of cirrhosis and congestive heart failure. Am J Physiol. 1991;260:R298305.

5 DiBona GF, Jones SY, Sawin LL. Reflex influences on renal nerve activity characteristics in nephrosis and heart failure. J Am Soc Nephrol. 1997;8(8):1232-9.

6 Bhatt DL, Kandzari DE, O'Neill WW, D'Agostino R, Flack JM, Katzen BT, et al. A controlled trial of renal denervation for resistant hypertension. N Engl J Med. 2014 Apr 10; 370(15):1393-401.

7 Azizi M, Schmieder RE, Mahfoud F, Weber MA, Daemen J, Davies J, et al. Endovascular ultrasound renal denervation to treat hypertension (RADIANCE-HTN SOLO): a multicentre, international, single-blind, randomised, sham-controlled trial. Lancet. 2018 Jun 9;391(10137):2335-45.

8 Kandzari DE, Bohm M, Mahfoud F, Townsend RR, Weber MA, Pocock S, et al. Effect of renal denervation on blood pressure in the presence of antihypertensive drugs: 6-month efficacy and safety results from the spyral htn-on med proof-of-concept randomised trial. Lancet. 2018 Jun 9;391(10137):2346-55.

9 Fukuta H, Goto T, Wakami K, Ohte N. Effects of catheter-based renal denervation on heart failure with reduced ejection fraction: a systematic review and meta-analysis. Heart Fail Rev. 2017 Nov;22(6):657-64.

10 Tang WHW, Dunlap ME. Reconsidering renal sympathetic denervation for heart failure. JACC Basic Transl Sci. 2017 Jun;2(3):282-4.

11 Böhm M, Ewen S, Wolf M. Renal denervation halts left ventricular remodeling and dysfunction in heart failure: new shores ahead. J Am Coll Cardiol. 2018 Nov 27;72(21):2622-4.

12 Fukuta H, Goto T, Wakami K, Kamiya T, Ohte N. Effects of catheter-based renal denervation on heart failure with reduced ejection fraction: a meta-analysis of randomized controlled trials. Heart Fail Rev. 2020 May 11.

13 Chen W, Ling Z, Xu Y, Liu Z, Su L, Du H, et al. Preliminary effects of renal denervation with saline irrigated catheter on cardiac systolic function in patients with heart failure: a prospective, randomized, controlled, pilot study. Catheter Cardiovasc Interv. $2017 \mathrm{Mar}$ 1;89(4):E153-E61.

14 Hopper I, Gronda E, Hoppe UC, Rundqvist B, Marwick TH, Shetty S, et al. Sympathetic response and outcomes following renal denervation in patients with chronic heart failure: 12 -month outcomes from the symplicity $\mathrm{hf}$ feasibility study. J Card Fail. 2017 Sep;23(9): 702-7.

15 Geng J, Chen C, Zhou X, Qian W, Shan Q. Influence of renal sympathetic denervation in patients with early-stage heart failure versus late-stage heart failure. Int Heart J. 2018 Jan 27;59(1):99-104.

16 Gao JQ, Yang W, Liu ZJ. Percutaneous renal artery denervation in patients with chronic systolic heart failure: a randomized controlled trial. Cardiol J. 2019;26(5):503-10.

17 Davies JE, Manisty CH, Petraco R, Barron AJ, Unsworth B, Mayet J, et al. First-in-man safety evaluation of renal denervation for chronic systolic heart failure: primary outcome from REACH-pilot study. Int J Cardiol. 2013 Jan 20;162(3):189-92.

18 Patel HC, Rosen SD, Hayward C, Vassiliou V, Smith GC, Wage RR, et al. Renal denervation in heart failure with preserved ejection fraction (RDT-PEF): a randomized controlled trial. Eur J Heart Fail. 2016 Jun;18(6):703-12.

19 Veelken R, Hilgers KF, Stetter A, Siebert HG, Schmieder RE, Mann JF. Nerve-mediated antidiuresis and antinatriuresis after air-jet stress is modulated by angiotensin II. Hypertension. 1996;28(5):825-32.

20 Veelken R, Hilgers KF, Porst M, Krause H, Hartner A, Schmieder RE. Effects of sympathetic nerves and angiotensin II on renal sodium and water handling in rats with common bile duct ligature. Am J Physiol Renal Physiol. 2005;288(6):F1267-75. 
21 DiBona GF, Jones SY, Sawin LL. Angiotensin receptor antagonist improves cardiac reflex control of renal sodium handling in heart failure. Am J Physiol. 1998;274(2 Pt 2):H636-41.

22 Kopp UC, Smith LA, DiBona GF. Impaired renorenal reflexes in spontaneously hypertensive rats. Hypertension. 1987 Jan;9(1):6975.

23 Kopp UC, Cicha MZ, Farley DM, Smith LA, Dixon BS. Renal substance P-containing neurons and substance $\mathrm{P}$ receptors impaired in hypertension. Hypertension. 1998 Mar;31(3): 815-22.

24 Ditting T, Hilgers KF, Stetter A, Linz P, Schonweiss C, Veelken R. Renal sympathetic nerves modulate erythropoietin plasma levels after transient hemorrhage in rats. Am J Physiol Renal Physiol. 2007 Oct;293(4): F1099-106.

25 Yoshiyama M, Takeuchi K, Omura T, Kim S, Yamagishi H, Toda I, et al. Effects of candesartan and cilazapril on rats with myocardial infarction assessed by echocardiography. Hypertension. 1999;33(4):961-8.

26 Mihic A, Cui Z, Wu J, Vlacic G, Miyagi Y, Li $\mathrm{SH}$, et al. A conductive polymer hydrogel supports cell electrical signaling and improves cardiac function after implantation into myocardial infarct. Circulation. 2015 Aug 25; 132(8):772-84

27 Burnstock G, Loesch A. Sympathetic innervation of the kidney in health and disease: emphasis on the role of purinergic cotransmission. Auton Neurosci. 2017 May;204:4-16.

28 Navar LG, Harrison-Bernard LM, Imig JD, Wang CT, Cervenka L, Mitchell KD. Intrarenal angiotensin II generation and renal effects of AT1 receptor blockade. J Am Soc Nephrol. 1999 Apr;10(Suppl 12):S266-72.

29 Pontes RB, Girardi AC, Nishi EE, Campos RR, Bergamaschi CT. Crosstalk between the renal sympathetic nerve and intrarenal angiotensin II modulates proximal tubular sodium reabsorption. Exp Physiol. 2015 Apr 20; 100(5):502-6.

30 Jennings DL. Heart failure therapy in 2016: shifting the paradigm from antiquated therapies toward novel agents. Ann Pharmacother. 2017 Jan;51(1):79-82.

31 Williams B, Mancia G, Spiering W, Agabiti Rosei E, Azizi M, Burnier M, et al. (2018 ESC/ ESH guidelines for the management of arterial hypertension. The task force for the management of arterial hypertension of the european society of cardiology (ESC) and the european society of hypertension (ESH)]. G Ital Cardiol. 2018 Sep 1;19(33):3S-73S.
32 Rodionova K, Fiedler C, Guenther F, Grouzmann E, Neuhuber W, Fischer MJ, et al. Complex reinnervation pattern after unilateral renal denervation in rats. Am J Physiol. 2016 May 1;310(9):R806-18.

33 Victor RG, Thoren P, Morgan DA, Mark AL. Differential control of adrenal and renal sympathetic nerve activity during hemorrhagic hypotension in rats. Circ Res. 1989 Apr;64(4): 686-94.

34 Dean C. Hemorrhagic sympathoinhibition mediated through the periaqueductal gray in the rat. Neurosci Lett. 2004 Jan 2;354(1):7983.

35 Mehta A, Dultz LA, Joseph B, Canner JK, Stevens $\mathrm{K}$, Jones $\mathrm{C}$, et al. Emergency general surgery in geriatric patients: a statewide analysis of surgeon and hospital volume with outcomes. J Trauma Acute Care Surg. 2018 Jun; 84(6):864-75.

36 Schultheis PJ, Clarke LL, Meneton P, Miller ML, Soleimani M, Gawenis LR, et al. Renal and intestinal absorptive defects in mice lacking the NHE3 $\mathrm{Na}+/ \mathrm{H}+$ exchanger. Nat Genet. $1998 \mathrm{Jul} ; 19(3): 282-5$.

37 Li XC, Hopfer U, Zhuo JL. AT1 receptor-mediated uptake of angiotensin II and NHE-3 expression in proximal tubule cells through a microtubule-dependent endocytic pathway. Am J Physiol. 2009 Nov;297(5):F1342-52.

38 Li XC, Hopfer U, Zhuo JL. Novel signaling mechanisms of intracellular angiotensin IIinduced NHE3 expression and activation in mouse proximal tubule cells. Am J Physiol. 2012 Dec 15;303(12):F1617-28

39 Banday AA, Lokhandwala MF. Angiotensin II-mediated biphasic regulation of proximal tubular $\mathrm{Na}+/ \mathrm{H}+$ exchanger 3 is impaired during oxidative stress. Am J Physiol. 2011 Aug; 301(2):F364-70.

40 Li XC, Zhu D, Chen X, Zheng X, Zhao C, Zhang J, et al. Proximal tubule-specific deletion of the NHE3 $(\mathrm{Na}+\mathrm{H}+$ Exchanger 3$)$ in the kidney attenuates ang II (Angiotensin II)induced hypertension in mice. Hypertension. 2019 Sep;74(3):526-35.

41 Peti-Peterdi J, Warnock DG, Bell PD. Angiotensin II directly stimulates ENaC activity in the cortical collecting duct via AT(1) receptors. J Am Soc Nephrol. 2002 May;13(5): 1131-5.

42 Komlosi P, Fuson AL, Fintha A, Peti-Peterdi J, Rosivall L, Warnock DG, et al. Angiotensin I conversion to angiotensin II stimulates cortical collecting duct sodium transport. Hypertension. 2003 Aug;42(2):195-9.
43 Prieto MC, Reverte V, Mamenko M, Kuczeriszka M, Veiras LC, Rosales CB, et al. Collecting duct prorenin receptor knockout reduces renal function, increases sodium excretion, and mitigates renal responses in ANG II-induced hypertensive mice. Am J Physiol Renal Physiol. 2017 Dec 1;313(6):F1243-F53.

44 Giles ME, Sly DJ, McKinley MJ, Oldfield BJ. A method for the identification of pseudorabies virus protein and angiotensin $\mathrm{AT}(1 \mathrm{~A}) \mathrm{re}-$ ceptor mRNA expression in the same CNS neurons. Brain Res Protoc. 2001 Dec;8(3): $153-8$.

45 Hay M, Edwards GL, Lindsley K, Murphy S, Sharma RV, Bhalla RC, et al. Increases in cytosolic $\mathrm{Ca} 2+$ in rat area postrema/mNTS neurons produced by angiotensin II and arginine-vasopressin. Neurosci Lett. 1993 Mar 19; 151(2):121-5.

46 Szabo B, Hedler L, Schurr C, Starke K. Peripheral presynaptic facilitatory effect of angiotensin II on noradrenaline release in anesthetized rabbits. J Cardiovasc Pharmacol. 1990; 15:968-75

47 Johns EJ. The role of angiotensin II in the antidiuresis and antinatriuresis induced by stimulation of the sympathetic nerves to the rat kidney. J Auton Pharmacol. 1987;7:20514.

48 Hall JE, Brands MW. Intrarenal and circulating angiotenisin II and renal function. In: Robertson JIS, Nichols MW, editors. The renin-angiotensin system. London,UK: Mosby; 1993. p. 26.1-26.43.

49 Dai Z, Yu S, Zhao Q, Meng Y, He H, Tang Y, et al. Renal sympathetic denervation suppresses ventricular substrate remodelling in a canine high-rate pacing model. EuroIntervention. $2014 \mathrm{Jul} ; 10(3): 392-9$.

50 Sharp TE 3rd, Polhemus DJ, Li Z, Spaletra P, Jenkins JS, Reilly JP, et al. Renal denervation prevents heart failure progression via inhibition of the renin-angiotensin system. J Am Coll Cardiol. 2018 Nov 27;72(21):2609-21.

51 Zheng H, Katsurada K, Liu X, Knuepfer MM, Patel KP. Specific afferent renal denervation prevents reduction in neuronal nitric oxide synthase within the paraventricular nucleus in rats with chronic heart failure. Hypertension. 2018 Jul 16.

52 Banek CT, Gauthier MM, Baumann DC, Van Helden D, Asirvatham-Jeyaraj N, Panoskaltsis-Mortari A, et al. Targeted afferent renal denervation reduces arterial pressure but not renal inflammation in established DOCA-salt hypertension in the rat. Am J Physiol Regul Integr Comp Physiol. 2018 Jun 1;314(6): R883-R91. 